\title{
Mapping of a gene for non-specific X linked mental retardation: evidence for linkage to chromosomal region Xp21.1-Xp22.3
}

\author{
Libor Kozák, Pietro Chiurazzi, Maurizio Genuardi, Maria Grazia Pomponi, \\ Marcella Zollino, Giovanni Neri
}

\begin{abstract}
Linkage analysis of a non-specific form of $X$ linked mental retardation (MRX) was performed with 16 polymorphic markers spanning the entire $X$ chromosome in a three generation Italian family, including four male patients with moderate mental retardation. One obligate carrier woman had mild mental retardation and another two had normal intelligence. The results indicate tight linkage to DNA markers DXS84 (L754), DXS164 (pERT87-15), and DXS278 (CRI-S232). A maximum lod score of 2.11 at $\theta=0.00$ was obtained with DXS164 and DXS278. The linked region spanned chromosomal bands Xp21.1-Xp22.3, that is, the same portion of the $X$ chromosome where MRX2 and MRX10-13 have been previously localised.

(f Med Genet 1993;30:866-9)
\end{abstract}

$\mathrm{X}$ linked mental retardation (XMLR) is a widely used term, collectively denoting the fragile $\mathrm{X}$ syndrome and a large number of less common conditions, some of which are syndromal, that is, characterised by a distinct phenotype, while others are not accompanied by any physical abnormalities and can only be

Received 11 February 1993 Revised version accepted 4 May 1993. distinguished on the basis of regional mapping on the $\mathrm{X}$ chromosome. ${ }^{1}$ The latter group of disorders are referred to as non-specific mental retardation, abbreviated to $\mathrm{MRX} .^{2}$ A total of 13 forms have been reported so far (MRX113),,$^{3-11}$ to which more recently another one was added. ${ }^{12}$ A large overlap of the regions to which these 14 loci have been assigned causes a nosological problem which is impossible to resolve at present, although a minimum of four distinct loci must exist in Xp22, Xp21, Xp11$\mathrm{q} 21$, and Xq27-q28. Analysis of additional large MRX families is needed to obtain a better picture of the number and location of the corresponding loci.

Here we report linkage data on another MRX family, assigning the mutant gene locus to the $\mathrm{Xp21.1-pter}$ region.

\section{Materials and methods \\ CLINICAL REPORT}

A three generation Italian family included four male patients with moderate mental retardation without any specific and consistent phenotypic abnormalities (fig 1). A group picture of the four affected males is shown in fig 2 . The proband (III.2) was born after an uneventful pregnancy. When first seen at 14 years 7 months, he was $172 \mathrm{~cm}$ tall (between the 75th and the 90th centile), weighed $55 \mathrm{~kg}$ (between the 50th and the 75 th centile), and his occipitofrontal circumference (OFC) was $55.5 \mathrm{~cm}$ (50th centile). Physical examination showed an elongated face with synophrys, high nasal bridge, anteverted nostrils, high arched palate, long and hyperextensible fingers, umbilical hernia, and bilateral hip dislocation.

III.5 was examined at age 19 years 9 months. Height was $166 \mathrm{~cm}$ (10th centile), weight $83 \mathrm{~kg}$ ( $>97 \mathrm{th}$ centile), and OFC $58 \mathrm{~cm}$ (around the 98th centile). He had divergent strabismus of the right eye, a prominent nasal root, short philtrum, and prominent chin with prognathism.

II.7, when examined at the age of 30 years, was $156 \mathrm{~cm}$ tall ( $>10$ th centile) and weighed $57 \mathrm{~kg}$ (between 10th and 25th centile). OFC was $58 \mathrm{~cm}$ (just below the 98 th centile). A prominent nasal root, short philtrum, high arched palate, small auricles, and bilateral
Figure 1 Pedigree of the family. Subject I.1, although not formally tested, is of low-normal intelligence. 


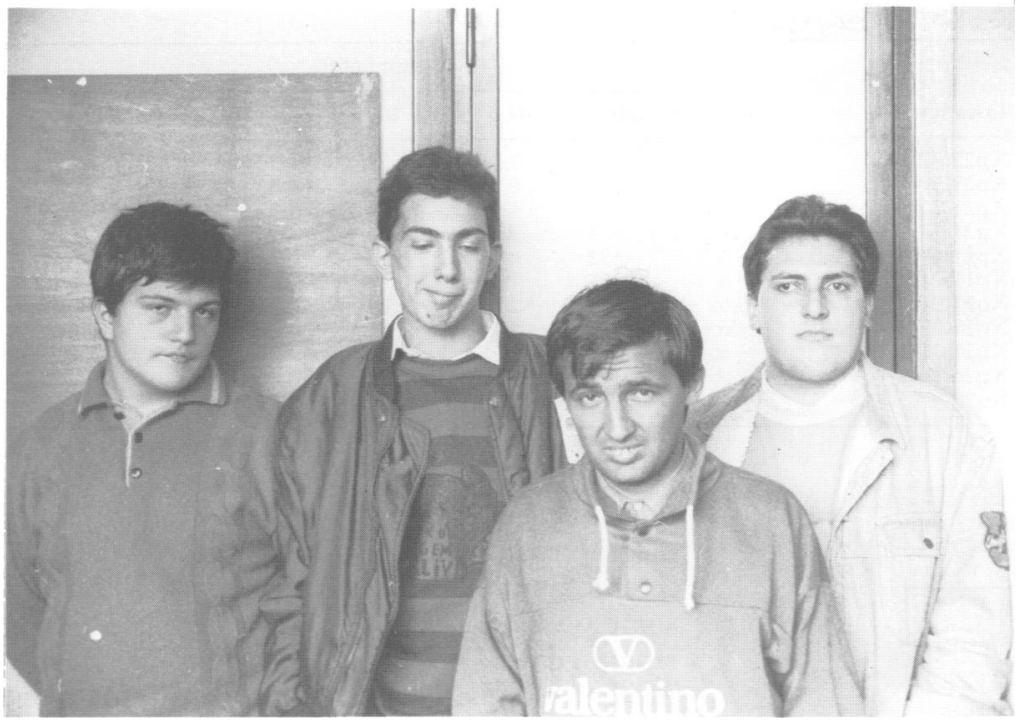

Figure 2 Photographs of the affected males of the family. From left to right are III.1, III. 2, II.7, and III.5.

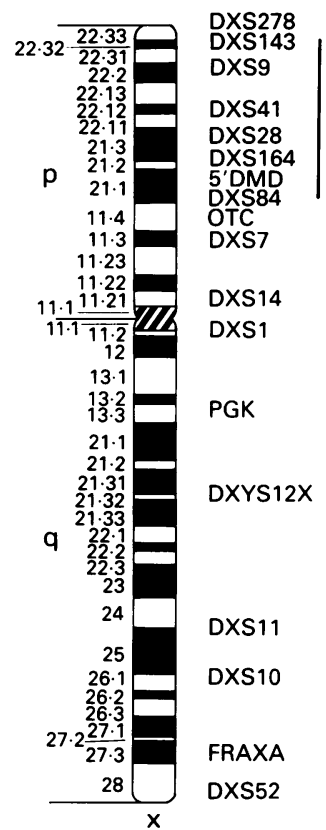

Figure 3 List and locations of $X$ chromosomal DNA markers used for linkage analysis and location of the MRX locus identified by the present study (indicated by the vertical bar). 5'DMD indicates the position of the brain promoter of the dystrophin gene, and FRAXA indicates the FMR-1 gene. single transverse palmar crease were noted on clinical examination.

III.1 was not personally examined. A prominent and wide nasal root, short philtrum, and small mouth were observed on photographs provided by other relatives.

All of the affected males had a history of delayed psychomotor development in infancy. They began to walk and pronounce their first words around 2 years. Brain CT scan was carrier woman (II.1) had mild mental retardation but no phenotypic abnormalities; another two (II.3 and II.5) had normal intelligence. I.1, although not formally tested, appeared to be of low-normal intelligence.

\section{CHROMOSOME ANALYSIS}

Chromosomes were prepared from peripheral lymphocytes by standard techniques and analysed after $G$ banding. Low folate cultures with fluorodeoxyuridine, specific for the fragile $\mathrm{X}$, were also performed.

\section{$X$ CHROMOSOME PROBES}

A total of 16 polymorphic $\mathrm{X}$ chromosome DNA markers and one FMR-1 probe (fig 3) were tested. Probes St14-1 (DXS52), CRIS232 (DXS278), and OX1.9 (FMR-1) were kindly provided by Drs J-L Mandel, G Camerino, and $\mathrm{K} E$ Davies, respectively. Other probes were obtained from ATCC.

\section{DNA ANALYSIS}

Genomic DNA was extracted from lymphocytes of venous blood from 10 available members of the family by standard procedures. DNA samples $(10 \mu \mathrm{g})$ were digested with restriction endonucleases detecting known RFLPs with map positions established on the $\mathrm{X}$ chromosome. ${ }^{13}$ The resulting fragments were separated by electrophoresis on $0.8 \%$ agarose (Sigma), blotted onto nylon membrane normal in all four affected males. One obligate
(Hybond $\mathrm{N}^{+}$, Amersham), and fixed according to standard procedures. ${ }^{14}$ Prehybridisation was done for one hour at $65^{\circ} \mathrm{C}$ in $0.5 \mathrm{~mol} / 1 \mathrm{Na}$ phosphate, pH 6.7, 7\% SDS, $1 \%$ BSA, and $0.2 \mathrm{mmol} / 1$ EDTA. The filters were hybridised overnight at $65^{\circ} \mathrm{C}$ in $0.5 \mathrm{~mol} / 1 \mathrm{Na}$-phosphate, pH $6.7,7 \%$ SDS, and $0.2 \mathrm{mmol} / 1$ EDTA in the presence of a probe radioactively labelled with ${ }^{32} \mathrm{P}-\mathrm{dCTP}$ by random priming (Amersham) to a specific activity of $10^{9} \mathrm{cpm} / \mu \mathrm{g}$. Nylon membranes were washed in $0.1-0.5$ $\times \mathrm{SSC} / 0 \cdot 1 \%$ SDS depending on the required stringency. Signals were detected by autoradiography on Kodak $x$ ray film at $-80^{\circ} \mathrm{C}$ for three to six days using an intensifying screen.

The brain promoter region of the dystrophin gene was tested by the polymerase chain reaction (PCR) according to the conditions described by Boyce et al..$^{15}$

Two point linkage analysis between 11 informative markers and the disease locus was performed using the computer program LIPED on data from 10 available members of the family.

\section{Results}

Clinical examination of the affected males and their position in the family pedigree was indicative of a non-specific form of $\mathrm{X}$ linked mental retardation. In fact, although prominent nasal bridge, high arched palate, and short philtrum were recurrent traits, there was not a consistent phenotype. For instance, in contrast to his affected uncle and cousins, the proband (III.2) had a marfanoid habitus.

Cytogenetic analysis of all affected males was negative for the fragile $\mathrm{X}$ or other structural anomalies of the X chromosome. Since no amplification of the FMR-1 trinucleotide CCG repeat was detected (data not shown), the most common mutation causing the fragile $\mathrm{X}$ syndrome could be definitely excluded. These findings, together with the absence of a syndromal clinical phenotype, led to the classification of this family as MRX.

Results of the two point linkage analysis are shown in the table. Tight linkage without recombination was found between the putative gene and the polymorphic DNA markers DXS84 (Xp21.1), DXS164 (Xp21.2), DXS28 (Xp21.3), and DXS278 (Xp22.32). Fig 4 shows a representative Southern blot containing DNA from nine family members. Mental retardation segregates with haplotype $A$ of the multiallelic probe DXS278. Maximal two point lod scores were $2 \cdot 11$ at recombination fraction $(\theta) \quad 0.00$ for both DXS164 and DXS278.

Because the maximal lod score was obtained at locus DXS164, which is located inside the dystrophin gene, a candidate locus for MRX, ${ }^{11} 15$ we tested the hypothesis that a deletion in the dystrophin brain promoter could be responsible for the observed MRX. The presence of a normal amplification product from the promoter region in all patients excluded the assumption that such a deletion is responsible for the present case of MRX (data not shown). 
Results of two point linkage analysis for MRX versus $X$ chromosome marker loci.

\begin{tabular}{|c|c|c|c|c|c|c|c|c|c|}
\hline \multirow[b]{2}{*}{ Probe } & \multirow[b]{2}{*}{ Locus } & \multirow[b]{2}{*}{ Location } & \multicolumn{7}{|c|}{ Lod score at $\theta$} \\
\hline & & & 0.00 & 0.01 & 0.05 & $0 \cdot 10$ & 0.20 & $0 \cdot 30$ & 0.40 \\
\hline $\begin{array}{l}\text { CRI-S232 } \\
\text { C7 } \\
\text { pERT87-15 } \\
\text { L754 } \\
\text { L1.28 } \\
\text { p58-1 } \\
\text { p8 } \\
\text { pXPGK-R10.9 } \\
\text { St25-1 } \\
\text { 36B-2 } \\
\text { St14-1 }\end{array}$ & $\begin{array}{l}\text { DXS278 } \\
\text { DXS28 } \\
\text { DXS164 } \\
\text { DXS84 } \\
\text { DXS7 } \\
\text { DXS14 } \\
\text { DXS1 } \\
\text { PGK1 } \\
\text { DXYS12X } \\
\text { DXS10 } \\
\text { DXS52 }\end{array}$ & $\begin{array}{l}\text { Xp22.32 } \\
\text { Xp21.3 } \\
\text { Xp21.2 } \\
\text { Xp21.1 } \\
\text { Xp11.4-p11.3 } \\
\text { Xp11.21 } \\
\text { Xq11.2-q12 } \\
\text { Xq13.3 } \\
\text { Xq21.31-q21.33 } \\
\text { Xq26.1 } \\
\text { Xq28 }\end{array}$ & $\begin{array}{l}2 \cdot 11 \\
0.90 \\
2 \cdot 11 \\
1 \cdot 81 \\
-\infty \\
-\infty \\
-\infty \\
-\infty \\
-\infty \\
-\infty \\
-\infty\end{array}$ & $\begin{array}{r}2 \cdot 07 \\
0 \cdot 89 \\
2 \cdot 07 \\
1 \cdot 77 \\
-0.52 \\
-2 \cdot 51 \\
-4 \cdot 51 \\
-4 \cdot 80 \\
-2 \cdot 73 \\
-1 \cdot 11 \\
-1 \cdot 11\end{array}$ & $\begin{array}{r}1.93 \\
0.81 \\
1.93 \\
1.63 \\
0.09 \\
-1.19 \\
-2.46 \\
-2.72 \\
-1.38 \\
-0.46 \\
-0.46\end{array}$ & $\begin{array}{r}1.74 \\
0.72 \\
1.74 \\
1.44 \\
0.28 \\
-0.67 \\
-1.63 \\
-1.84 \\
-0.84 \\
-0.23 \\
-0.23\end{array}$ & $\begin{array}{r}1.33 \\
0.52 \\
1.33 \\
1.03 \\
0.35 \\
-0.25 \\
-0.86 \\
-0.99 \\
-0.36 \\
-0.06 \\
-0.06\end{array}$ & $\begin{array}{r}0.88 \\
0.30 \\
0.88 \\
0.59 \\
0.28 \\
-0.09 \\
-0.46 \\
-0.52 \\
-0.14 \\
-0.01 \\
-0.01\end{array}$ & $\begin{array}{r}0.41 \\
0.09 \\
0.41 \\
0.17 \\
0.16 \\
-0.02 \\
-0.20 \\
-0.21 \\
-0.03 \\
-0.01 \\
-0.01\end{array}$ \\
\hline
\end{tabular}

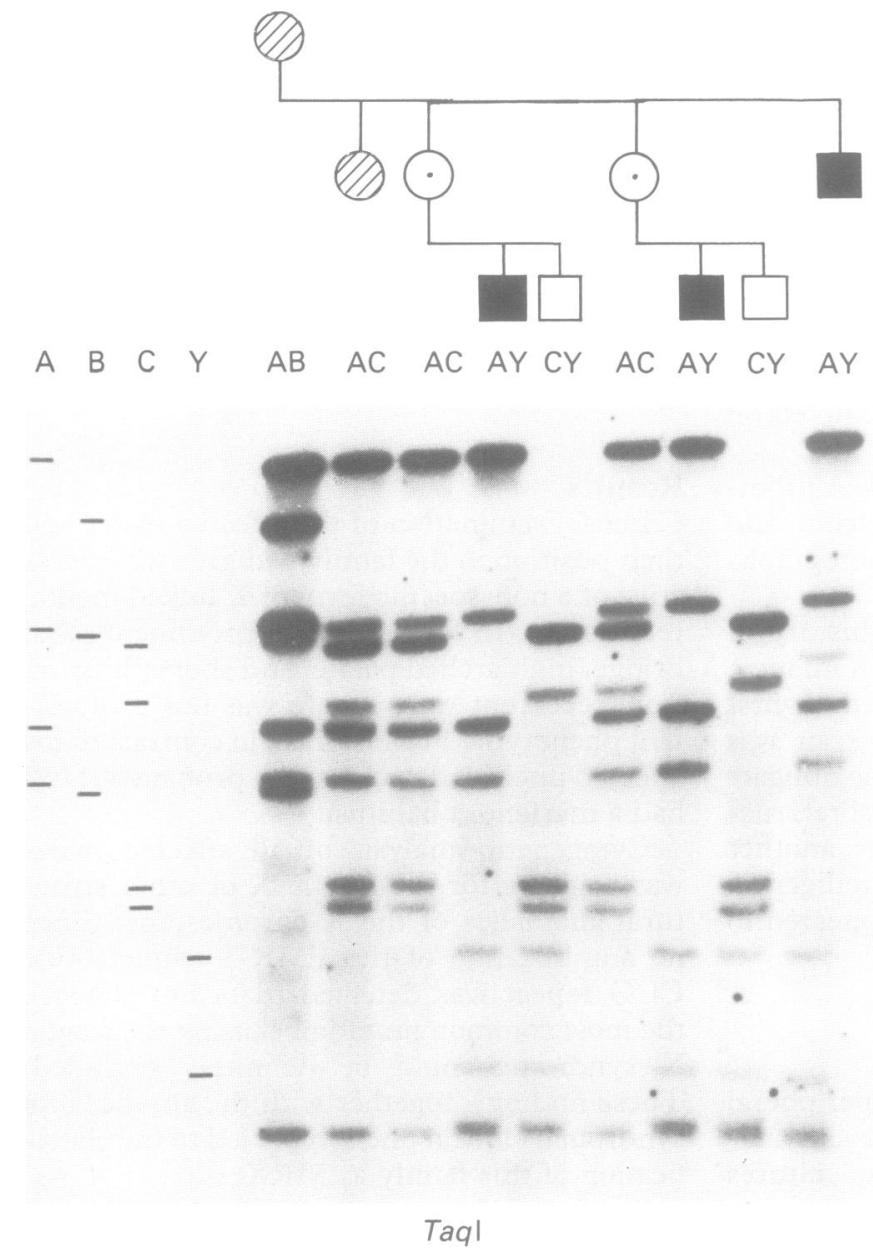

Figure 4 Representative Southern blot showing haplotypes designated A,B,C (from the $X$ chromosome), and $Y$ (from the $Y$ chromosome) detected with the restriction enzyme TaqI and the DNA probe DXS278. No recombination was observed between the putative MRX gene and the $A$ haplotype. Each obligate carrier woman and three affected males inherited haplotype $A$, while two unaffected males inherited haplotype $C$. The restriction fragments composing each haplotype are shown schematically on the left of the autoradiogram. Letters above each lane indicate the two haplotypes inherited by the corresponding subject.

\section{Discussion}

The data obtained in this study suggest a location of the locus responsible for MRX in this family in the distal portion of $\mathrm{Xp}$, between bands Xp21.1 and Xp22.3. Lack of recombination events for markers in the region distal to $\mathrm{Xp} 21.1$ prevented a more precise delimitation of the region containing the affected locus.

By comparing our results with those defining the other 13 putative MRX loci, it is evident that these overlap quite extensively. It should be noted that each MRX locus has been defined by the study of a single family. It is unclear at the moment whether or not a single mental retardation locus is involved in different families, but it is quite possible that some of the overlapping loci correspond to a single gene. The linked portion of $\mathrm{Xp}$ in the present analysis has a similar position as in

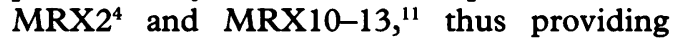
further support to the existence of at least one gene associated with MRX in Xp21.1-p22.3.

Recently the $\mathrm{X}$ chromosome has been very extensively investigated and many loci for non-specific mental retardation as well as syndromic mental retardation are being mapped. There is hope that in a short time we will know not only the number and the location of the genes responsible for mental retardation, but their molecular structure as well.

In the meantime, linkage data can be used for genetic counselling and prenatal diagnosis, although some problems are likely to be encountered. For instance, in our family it was impossible to decide whether subject II. 8 is a carrier or not, because a recombination occurred between DXS84 and DXS164. Since she does not have any children, it is impossible to tell whether this recombination also involves the locus of the mutation. At present, the only chance to predict her status (carrier or not carrier) would rely on an unlikely double recombination event within the candidate region, which could be tested by analysis of additional polymorphisms, especially of highly informative markers, such as dinucleotide repeats.

Libor Kozák and Maria Grazia Pomponi gratefully acknowledge the financial support of Regione Lazio, Assessorato Enti Locali e Servizi Sociali, and SIGMA-TAU, Roma, respectively.

1 Neri G, Chiurazzi P, Arena, F, Lubs HA, Glass AI. XLMR genes: update 1992. Am ₹ Med Genet 1992;43:373-82.

2 Davies KE, Mandel JL, Monaco AP, Nussbaum RL, Willard HF. Report of the committee on the genetic constitution of the $\mathrm{X}$ chromosome. Cytogenet Cell Genet 1991;58:1-117.

3 Suthers GK, Turner G, Mulley JC. A non-syndromal form of X-linked mental retardation (XLMR) is linked to DXS14. Am $\mathcal{F}$ Med Genet 1988;30:485-91.

4 Arveiler B, Alembik Y, Hanauer A, et al. Linkage analysis suggests at least two loci for $\mathrm{X}$-linked non-specific mental suggests at least two loci for X-linked non-specifo
retardation. Am $\mathcal{F}$ Med Genet 1988;30:473-83.

5 Gedeon A, Kerr B, Mulley J, Turner G. Localisation of the MRX 3 gene for non-specific X linked mental retardation. I Med Genet 1991;28:372-7.

6 Samanns C, Albrecht R, Neugebauer M, Neri G, Gal A. Gene for non-specific X-linked mental retardation maps in the pericentromeric region. Am $\mathcal{J}$ Med Genet in the pericentro.

7 Kondo I, Tsukamoto K, Niikawa N, Okano K, Kanazawa I, Hupkes PE. A new form of X-linked mental retardation Hupkes PE. A new form of X-linked mental retardation
(XLMR) linked to DXS369 (RN1). Cytogenet Cell Genet (XLMR) linked to DXS369 (RN1). Cytogenet Cell Genet

8 Jedele KB, Michels VV, Wagner KV, Schaid DJ, Thibo- 
deau SN. Linkage analysis demonstrating association of DXYS1 and non-specific X-linked mental retardation. Am 7 Hum Genet 1990;47:A62.

9 Schwartz CHE, Tay M, Huang T, et al. An X-linked mental retardation condition with linkage to $\mathrm{Xq} 21 . \mathrm{Am} \mathfrak{f}$ Med Genet 1992;43:467-74.

10 Willems PJ, Buntinx I, Vits L, Raeymaekers P. Localization of a gene responsible for nonspecific mental retardation of a gene responsible for nonspecific mental retarda-

11 Kerr B, Gedeon A, Mulley J, Turner G. Localization of non-specific X-linked mental retardation genes. $A m \mathcal{F}$ Med Genet 1992;43:392-401.

12 Wilson GN, Richards CS, Katz K, Brookshire GS. Non- specific $\mathrm{X}$ linked mental retardation with aphasia exhibiting genetic linkage to chromosomal region Xp11. F Med Genet 1992;29:629-34.

13 Williamson R, Bowcock A, Kidd K, et al. Report of DNA committee and catalogues of cloned and mapped genes, markers formatted for PCR and DNA polymorphisms. Cytogenet Cell Genet 1991:58:1190-832.

14 Sambrook J, Fritsch EF, Maniatis T. Molecular cloning: a laboratory manual. New York: Cold Spring Harbor Laboratory Press, 1989.

15 Boyce MF, Beggs AH, Feener Ch, Kunkel LM. Dystrophin is transcribed in brain from a distant upstream promoter. Proc Natl Acad Sci USA 1991;88:1276-80. 